\title{
Benthic metabolism in San Quintin Bay, Baja California, Mexico
}

\author{
Silvia E. Ibarra-Obando ${ }^{1, *}$, Stephen V. Smith ${ }^{1}$, Miriam Poumian-Tapia ${ }^{1}$, \\ Victor Camacho-Ibar ${ }^{2}$, José D. Carriquiry ${ }^{2}$, Martin Montes-Hugo ${ }^{1}$ \\ ${ }^{1}$ Centro de Investigación Científica y Educación Superior de Ensenada (CICESE), Km 107 Carretera Tijuana-Ensenada, \\ Ensenada, Baja California, Mexico \\ ${ }^{2}$ Instituto de Investigaciones Oceanológicas, Universidad Autónoma de Baja California, Km 103 Carretera Tijuana-Ensenada, \\ Ensenada, Baja California, Mexico
}

\begin{abstract}
Benthic metabolism was measured at 3 representative lagoon bottom sites in San Quintin Bay, Baja California, Mexico, during winter and summer from 1997 to 2000. At each site, and in every sampling period, three $0.5 \mathrm{~m}$ diameter transparent acrylic hemispherical domes were installed on bare sediment for $\sim 24 \mathrm{~h}$ to determine fluxes of dissolved inorganic carbon (DIC), total alkalinity (TA), dissolved oxygen $\left(\mathrm{O}_{2}\right)$ and dissolved inorganic nutrients $\left(\mathrm{NH}_{4}, \mathrm{PO}_{4}\right)$. Our results for sediment fluxes (mean $\pm \mathrm{SE} ; \mathrm{n}=63$ ), all in $\mathrm{mmol} \mathrm{m} \mathrm{m}^{-2} \mathrm{~d}^{-1}$, except $\mathrm{TA}$ in meq $\mathrm{m}^{-2} \mathrm{~d}^{-1}$ were: $\mathrm{O}_{2}=-23.4$ $( \pm 10.7) ; \mathrm{DIC}=31.0( \pm 22.9) ; \mathrm{TA}=8.1( \pm 8.0) ; \mathrm{NH}_{4}=2.15( \pm 1.39) ; \mathrm{PO}_{4}=0.114( \pm 0.140)$. These values fall near the median of values reported for shallow water systems. The benthic and planktonic metabolic rates were also compared. Seagrass beds were apparently responsible for $\sim 80 \%$ of the benthic metabolism. Benthic processes dominate the metabolism at the system level, accounting for about $\sim 70 \%$ of total primary production (PP) and respiration (R). A whole-system production to respiration ratio of $\sim 0.9$ was obtained. While recycling dominates gross metabolism, there must be an external supply of organic material to account for an excess of R over PP (net heterotrophy). We conclude that plankton external supplied from outside the system dominates this external supply. Our data agree with previous information for Tomales Bay, California, that deep sediment DIC release was about twice $\mathrm{O}_{2}$ uptake. These results indicate that anaerobic metabolism accounted for about half the net respiration in the deep sediments.
\end{abstract}

KEY WORDS: Nutrient fluxes · Gross metabolism · Benthic-pelagic coupling · Seagrass · Temperate coastal lagoon Resale or republication not permitted without written consent of the publisher

\section{INTRODUCTION}

In shallow estuaries and lagoons, organic carbon production, sedimentation, and various aerobic and anaerobic respiration pathways (remineralization) link benthos and water column metabolism (Kemp \& Boynton 1984, Jørgensen \& Sørensen 1985, Rizzo 1990, Dollar et al. 1991, Kemp et al. 1992). Unlike planktondominated deep ocean systems, both the benthos and water column figure prominently in both the primary production and the respiration of these shallow systems. Time scales of this coupling tend to be from hours to days (Nixon 1981, Smith \& Hollibaugh 1993, 1997, D'Avanzo et al. 1996). A strong linear relation- ship between the amount of organic matter produced and/or imported and the amount of organic matter consumed on the bottom has been described for coastal marine ecosystems (Hargrave 1973, Nixon 1981, Hopkinson 1985, Smith \& Hollibaugh 1993).

By analyzing the magnitude and ratios of benthic nutrient, carbon and oxygen fluxes, it is possible to gain insight into the pathways of carbon, nitrogen and phosphorus cycling, and the factors that control them at a given location (e.g. Nixon 1981, Dollar et al. 1991, Forja et al. 1994, Giblin et al. 1997). When benthic metabolic rates are compared with water column rates, it is possible to assess their individual contribution to total-system carbon and nutrient cycles, both tempo- 
rally and spatially (Nixon \& Pilson 1984, Kemp et al. 1997, Smith \& Hollibaugh 1997). Despite the relevance of the geochemical and ecological information obtained through 'stoichiometric analysis' of flux ratios, few studies have used it. The approach has seen wider use over the past decade as part of the IGBP-LOICZ project, largely as a way to retrieve information about ecosystem metabolism from secondary data (http:// data.ecology.su.se/MNODE/).

We were interested in describing benthic metabolism in San Quintin Bay, Baja California, Mexico, a temperate climate marine lagoon system, to answer the following questions: (1) How large is the contribution of benthic metabolism (production and respiration) to ecosystem-level metabolism? (2) Which are the spatial patterns in benthic fluxes between and within habitats? (3) What controls the magnitude and stoichiometric ratios of benthic fluxes? San Quintin Bay is hydrographically and climatically similar to Tomales Bay, California, USA, an extensively studied system approximately $1000 \mathrm{~km}$ to the northwest (e.g. Smith \& Hollibaugh 1997 and references therein). Therefore, (4) how similar is the biogeochemical functioning of these 2 bays, when analyzed with internally consistent methodology?

Much of the coastal ocean is profoundly impacted by human activities and by climate change and variability. Therefore, a further interest of this site comparison is due to the fact that these 2 systems are both relatively unimpacted (Smith \& Hollibaugh 1997, AguirreMuñoz et al. 2001). Less information exists on the fate and transport of nutrients in coastal lagoons and bays receiving relatively little terrestrial inputs, than for river-dominated coastal plain estuaries (Boynton et al. 1996, Largier et al. 1997). As development pressure continues in the coastal zone, there is an urgent need to understand ecosystem functioning in less disturbed conditions such as in San Quintin and Tomales Bays.

\section{MATERIALS AND METHODS}

Study area. San Quintin Bay is located at $30^{\circ} 30^{\prime} \mathrm{N}$, $116^{\circ} \mathrm{W}$, on the Pacific coast of Baja California about $300 \mathrm{~km}$ south of the Mexico-USA border (Fig. 1). It covers an area of $42 \mathrm{~km}^{2}$ and has a mean depth of about $2 \mathrm{~m}$. Tides are semidiurnal with a mean amplitude of 1.6 m (C. Nava, Sea Level Laboratory, CICESE, pers. comm.). The most conspicuous benthic community in the system is the eelgrass (Zostera marina) (IbarraObando \& Huerta-Tamayo 1987, Poumian-Tapia \& Ibarra-Obando 1999). Ward et al. (2003) assessed changes in major habitat coverage between 1987 and 2000. As simplified and generalized from Ward et al.
(2003), marine habitats are represented by exposed and submerged eelgrass, mudflat, channel (deep mud) and salt marsh (Fig. 1).

Whole-system net biogeochemical characteristics have been described by Camacho-Ibar et al. (2003), and characteristics of anthropogenic use of the bay and its interaction with the adjacent land are described by Aguirre-Muñoz et al. (2001).

Methodology. Two sets of primary data are presented in this paper. Measuring metabolism of the deep channel sediments was the major thrust of the study. Therefore, procedures for those measurements are detailed below and are the major topic presented in the Results. In addition, we estimated metabolism in the water column. This constitutes a relatively minor portion of the 'Results'.

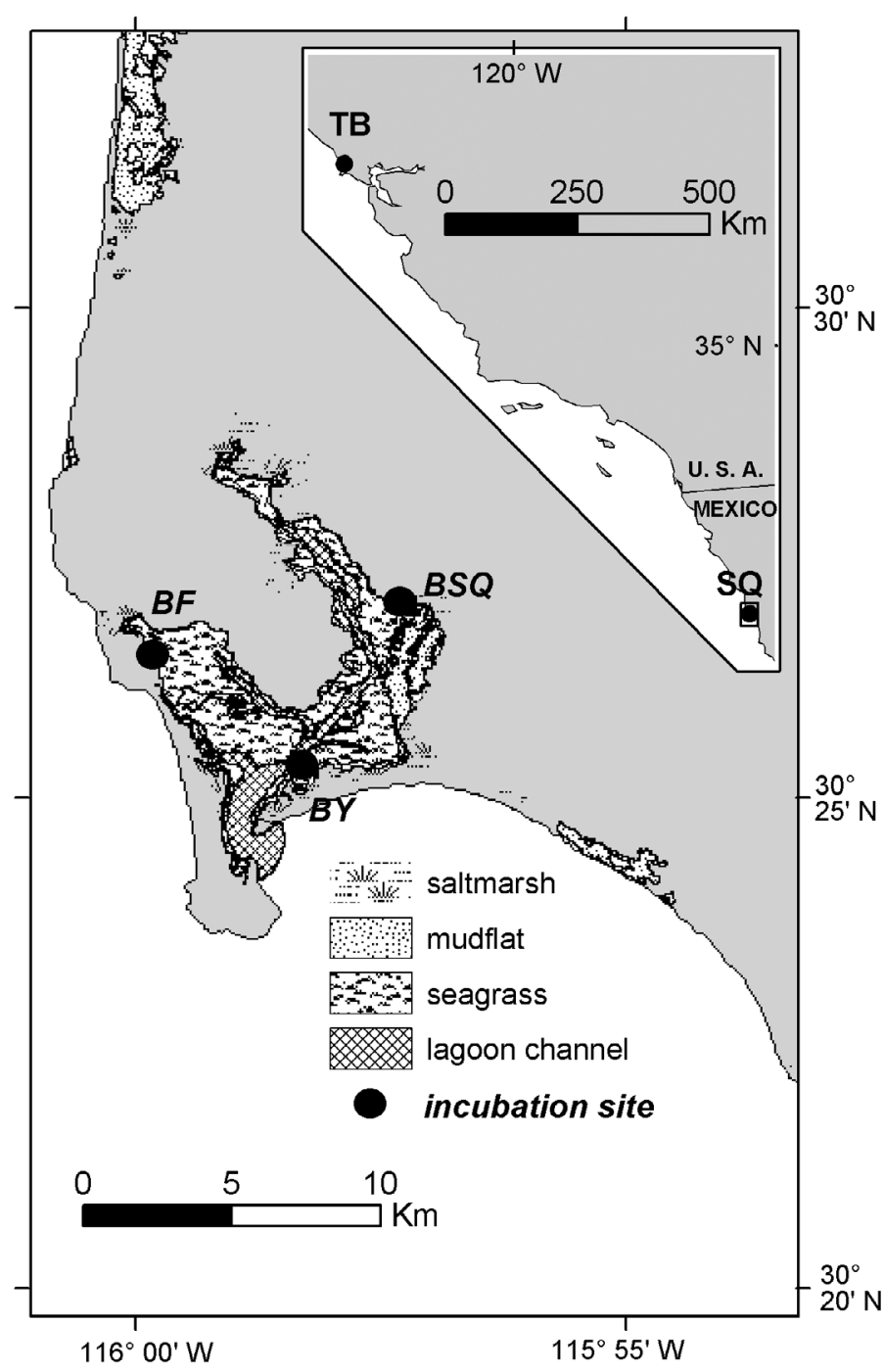

Fig. 1. San Quintin Bay, Baja California (SQ), also showing location of Tomales Bay, California (TB) (inset). The main habitats described in Ward et al. (2003) are shown. Full circles indicate experimental sites 
Because we wished to consider other aspects of total system metabolism and to compare our results with other coastal systems, we also undertook a relatively detailed (although hardly comprehensive) literature survey both of San Quintin Bay and of the broader coastal ecological literature. Our database (http:// ecologia.cicese. $\mathrm{mx} / \sim$ sibarra) on benthic fluxes includes a total of 75 references from shallow $(<20 \mathrm{~m})$ and deep (20 to $100 \mathrm{~m}$ ) coastal sites. This $20 \mathrm{~m}$ depth was used as a cut-off between 'shallow' and 'deep' sites, because there was a natural break in the frequency distribution near $20 \mathrm{~m}$, with a scattering of sites at greater depths. The database on benthic-pelagic coupling includes 29 references from 17 sites. For comparative purposes, only those studies in coastal environments, in which fluxes were measured on sediments devoid of macroscopic vegetation, were included. The final data base for benthic fluxes consists of 61 references from 57 locations. In the case of benthic-pelagic coupling, the final database consists of 28 references from 16 locations. We also conducted a literature survey of data on microphytobenthos production from coastal temperate ecosystems, available at the same web page as above. This database contains 32 references for 29 sites.

Deep sediment fluxes. Sampling took place each February and August between February 1997 and February 2000. These sampling periods were assumed to capture the winter and summer extremes of the annual cycle, have similar length and provide comparison with the Tomales Bay study (Dollar et al. 1991). In Tomales, whole-system and benthic metabolic rates were represented by an essentially saw-toothed oscillation between winter low values during the January bimonthly sampling and summer high values in August (Smith \& Hollibaugh 1997). We therefore estimate annual average values as the averages of the February and August data (properly weighted for 4 February and 3 August sampling periods).

We used the subsystems previously described by Camacho-Ibar et al. $(1999,2003)$ to choose our 3 sampling locations: Bahia San Quintin (BSQ), Bahia Falsa (BF) and Base of the Y (BY) respectively (Fig. 1). As in Dollar et al. (1991), transparent plexiglas hemispherical domes $50 \mathrm{~cm}$ in diameter enclosing a water volume of approximately $33 \mathrm{l}$ were used. On each sampling period, 3 domes were deployed for approximately $24 \mathrm{~h}$ in water depths of about $4 \mathrm{~m}$, over sediment devoid of macroscopic vegetation, at each of the 3 locations. The $4 \mathrm{~m}$ depth was considered to represent the mean depth of channels.

As we did not have funds for stirrers, the possibility of reduced oxygen concentration at the sedimentwater interface of the domes existed. Considering this, and because our preliminary summer data indicated that after periods much longer than $12 \mathrm{~h}$, oxygen in the domes could be exhausted, it was decided to deploy the domes and then move them about $0.5 \mathrm{~m}$ after halfday periods. This procedure allowed complete replacement of the water in the dome, assuring that there would be enough oxygen to complete the $24 \mathrm{~h}$ incubation period. This procedure was followed, both in summer and winter, for internal consistency.

Four sets of water samples were withdrawn from each dome at each location during a $1 \mathrm{~d}$ incubation: $t_{0}$, a few minutes after installation, allowing for most sediment to settle; $t_{1}$, after the day or night incubation period; $t_{2}$, after moving the domes and allowing time for sediment to settle; and $t_{3}$, after the additional incubation period. Fluxes were estimated for the periods $\left(t_{1}-t_{0}\right)$ and $\left(t_{3}-t_{2}\right)$. Water samples were collected into $140 \mathrm{ml}$ plastic syringes withdrawn through a stopcock, while a second stopcock remained open to allow replacement of the sample volume with bay water. Our calculations indicated that the water volume replaced during sampling represented $2 \%$ of dome volume. Four syringes were filled per dome at each sampling interval. Syringes were kept $<1 \mathrm{~h}$ in an empty Styrofoam ice chest, near ambient temperature, during transport to the laboratory.

Once samples were in the laboratory, dissolved oxygen and temperature were measured directly in the syringes with a YSI 58 digital oxygen meter (nominal precision $0.01 \mathrm{mg} \mathrm{l}^{-1}$ ); $\mathrm{pH}$ was measured in the same syringe with a 290A Orion pH meter (nominal precision $0.002 \mathrm{pH}$ units). The oxygen electrodes were air calibrated at the beginning of each measurement sequence. Water samples for other analyses were filtered through GFC filters. Filters were kept frozen in the dark for chlorophyll a determination. About $75 \mathrm{ml}$ of filtered water was held at room temperature for total alkalinity (TA) measurement within the next few days by the method of single-point acid $(0.01 \mathrm{~N} \mathrm{HCl})$ addition, and determination of $\mathrm{pH}$ of the acidified sample (Smith \& Kinsey 1978). Water samples for dissolved inorganic nutrient measurement $\left(\mathrm{NH}_{4} ; \mathrm{PO}_{4}\right)$ were filtered into $\mathrm{HCl}$-washed, sample-rinsed polyethylene bottles and kept frozen until analyzed. $\mathrm{NO}_{3}$ was not measured, as pilot studies demonstrated the $\mathrm{NO}_{3}$ fluxes to be small and inconsistent in direction (see also Dollar et al. 1991, for Tomales). Samples for 1997, 1998 and winter 1999 were analyzed with a Milton Roy Plus Spectronic 1001 spectrophotometer using standard techniques described in Strickland \& Parsons (1972). Summer 1999 and winter 2000 samples were analyzed automatically using a segmented flow analysis system (S.F.A.S.) Skalar San Plus (precision $0.1 \mu \mathrm{M})$. Chlorophyll a was determined using fluorometric techniques as described in Strickland \& Parsons (1972). 
Benthic fluxes were calculated using the equation given by Dollar et al. (1991):

$$
J=V\left(C_{\mathrm{t}}-C_{0}\right) /(A T)
$$

where $J=$ benthic flux per unit area of bay bottom, $V=$ volume of water enclosed within the incubation chamber over the sediment $\left(\sim 0.033 \mathrm{~m}^{3}\right), C_{\mathrm{t}}$ and $C_{0}=$ dissolved concentrations at the end and beginning of each incubation period, $A=$ area of sediment enclosed $\left(\sim 0.20 \mathrm{~m}^{2}\right)$, and $T=$ time. It is implicit in the equation that positive fluxes release dissolved materials to the water column, while negative fluxes remove dissolved material out of the water column.

An initial comparison was made in the differences between day and night fluxes. Then, fluxes for day and night periods were cumulated in order to derive daily net fluxes. Rates from the 3 chambers were averaged at each site and on each date. Based on previous experience (Smith et al. 1981, Dollar et al. 1991, Smith \& Hollibaugh 1997), concentrations in the domes were assumed to vary linearly. Benthic fluxes were not corrected for water column metabolism as the average dome depth is small $(<10 \%$ of the average water column in the bay; $<5 \%$ of the depth at the deployment sites). Corrections for water column metabolism would be within the analytical errors of the flux estimates (see below).

Plankton metabolism. Primary production: In order to compare benthic and pelagic primary production, phytoplankton primary production was measured during one August and one February period, using the ${ }^{14} \mathrm{C}$ technique. In order to extend the results, we used an empirical model developed by Montes-Hugo (2001) and Montes-Hugo \& Alvarez-Borrego (2003) for San Quintin Bay. The primary difference between this model and the one developed by Cole (1989) for Tomales Bay is that we parameterize primary production as an exponential function of depth at each station $(\sim 4 \mathrm{~m})$ and attenuation coefficient (characteristically $\sim 0.6 \mathrm{~m}^{-1}$; measured several times during summer and winter ebb tides in 1999; see also Cabello-Pasini et al. 2003). Characteristic depths for 50,10 and 1\% light were approximately 1, 4 and $8 \mathrm{~m}$, respectively. Most of the bay is shallower than $4 \mathrm{~m}$.

Surface-water phytoplankton production was measured at the 3 sampling sites during August 1999 and February 2000. At each site, 3 sets of replicates were used. Each set consisted of 2 clear and 1 dark $250 \mathrm{ml}$ polycarbonate bottles inoculated with $5 \mu \mathrm{Ci}{ }^{14} \mathrm{C}$. Bottles were held at $1 \mathrm{~m}$ water depth for $2 \mathrm{~h}$ (11:00 to 13:00 h). Once in the laboratory, water samples were filtered through a Gelman $0.45 \mu \mathrm{m}$ filter that was kept in a scintillation vial to which we added $0.5 \mathrm{ml} \mathrm{HCl}$. After about $10 \mathrm{~h}, 10 \mathrm{ml}$ of a liquid scintillation cocktail (Ecolite) were added to the vial. Filters were read in a Beckman LSC-100 liquid scintillation counter at Scripps Institution of Oceanography. The amount of ${ }^{14} \mathrm{C}$ fixed was calculated with the equation given by Strickland \& Parsons (1972).

Respiration: Each time the domes were deployed, water samples for measurement of plankton respiration were collected from the surface into $20 \mathrm{l}$ carboys. Once in the laboratory, water was siphoned into 3 sets of replicate $300 \mathrm{ml}$ opaque glass BOD bottles, allowing overflow before capping. The bottles were incubated for $36 \mathrm{~h}$ in a water bath at field temperature $\left( \pm 0.5^{\circ} \mathrm{C}\right)$. Oxygen was measured in 2 replicate bottles from each set, at $12 \mathrm{~h}$ intervals over the $36 \mathrm{~h}$ (following Fourqurean et al. 1997). The oxygen meter and probe were calibrated at the beginning of each measurement sequence using water-saturated air at the temperature of incubation. The electrode was placed in each bottle and allowed to equilibrate until a constant reading was obtained.

Preliminary analyses demonstrated that respiration in the bottles consumed about $8 \mu \mathrm{mol} \mathrm{O} \mathrm{O}^{-1}$ over a $12 \mathrm{~h}$ period. This is a weak analytical signal. As seawater has typically about $200 \mu \mathrm{mol} \mathrm{O}_{2} \mathrm{l}^{-1}$, a change of only about $4 \%$ would have taken place over $12 \mathrm{~h}$. We, therefore, ran the incubations for $36 \mathrm{~h}$ in order to achieve total changes in the $10 \%$ range. While we recognize that this could introduce artifacts (slowed or accelerated respiration, largely dependent upon either exhausting the substrate or building up bacterial biomass), we saw no evidence of such rate changes in preliminary studies.

\section{RESULTS}

\section{Deep sediment fluxes in the incubation chambers}

End-point oxygen concentrations measured throughout all incubations ranged between 1.8 and $12.2 \mathrm{mg} \mathrm{l}^{-1}$, with a mode of $7.6 \mathrm{mg} \mathrm{l}^{-1}$ (Fig. 2). Measured fluxes were apparently not compromised by lack of oxygen, as oxygen saturation at the end of incubations was never below $20 \%$ and mostly above $60 \%$.

We considered the possibility that there were significant day versus night fluxes in the bay-channel sediments (Table 1). Only the summer DIC fluxes showed a significant day-night difference. Nighttime dissolved inorganic carbon (DIC) fluxes exceed daytime fluxes by $17 \mathrm{mmol} \mathrm{m}^{-2} \mathrm{~d}^{-1}$. TA, $\mathrm{O}_{2}$ and nutrient fluxes showed insignificant day versus night differences.

Fluxes over complete $24 \mathrm{~h}$ cycles for the 3 sites and for the whole bay are presented in Table 2. Further evidence that benthic fluxes were not affected by lack of oxygen comes from the scatterplot of $\mathrm{O}_{2}$ flux and 


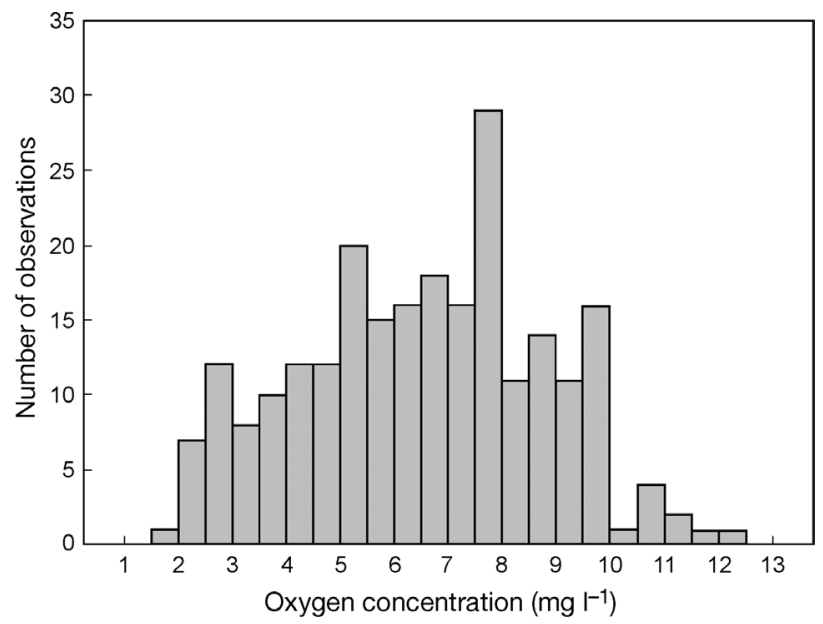

Fig. 2. Histogram showing the frequency of observations at the various oxygen concentrations $\left(\mathrm{mg} \mathrm{l}^{-1}\right)$ at the end of the incubations periods. Most of the values were above $2 \mathrm{mg} \mathrm{l}^{-1}$
DIC flux, which shows that there was a significant linear relationship between $\mathrm{O}_{2}$ consumption and DIC production (slope $\sim-1.9$; intercept near 0 ), indicating substantial anaerobic respiration, but no change of slope at high DIC production (Fig. 3). As both $x$ and $y$ variables are subject to errors, regression model II was applied (Ricker 1973). DIC flux is assumed to represent total organic matter oxidation and consistently exceeds $\mathrm{O}_{2}$ flux (except near 0).

Significant differences between sites were found for $\mathrm{O}_{2}$, DIC and $\mathrm{NH}_{4}$ fluxes. The stations in the 2 arms (BSQ and BF) are similar to one another and differ from the mouth (BY) (Table 3). BY consistently showed elevated fluxes relative to both $\mathrm{BSQ}$ and $\mathrm{BF}$. While the differences may represent spatial trends within regions of the bay, we cannot evaluate an appropriate spatial weighting or even interpret this as anything other than differences between the 3 stations. We, therefore, use

Table 1. Whole-bay comparison between daytime and nighttime fluxes. Values are $\mathrm{mmol} \mathrm{m}^{-2} \mathrm{~d}^{-1}$ except TA, which is meq $\mathrm{m}^{-2} \mathrm{~d}^{-1}$. Mean $\pm 1 \mathrm{SD}$ (number of samples). ${ }^{*}$ Day-night pairs significantly different from one another at $\mathrm{p}<0.05$ (summer DIC only); afluxes differ from 0 at $\mathrm{p}<0.05$. Note that 1 set of winter $\mathrm{NH}_{4}$ samples was lost and 1 summer value for TA flux was an outlier. DIC: dissolved inorganic carbon; TA: total alkalinity; $\mathrm{NH}_{4}$ : dissolved inorganic nitrogen; $\mathrm{PO}_{4}$ : dissolved inorganic phosphate

\begin{tabular}{|c|c|c|c|c|c|c|}
\hline & & $\mathrm{O}_{2}$ & DIC & TA & $\mathrm{NH}_{4}$ & $\mathrm{PO}_{4}$ \\
\hline Winter & $\begin{array}{l}\text { Day } \\
\text { Night }\end{array}$ & $\begin{array}{l}-14.6 \pm 13.7(36)^{\mathrm{a}} \\
-20.3 \pm 11.7(36)^{\mathrm{a}}\end{array}$ & $\begin{array}{l}18.0 \pm 23.0(36)^{\mathrm{a}} \\
18.8 \pm 29.4(36)^{\mathrm{a}}\end{array}$ & $\begin{array}{l}7.7 \pm 9.6(36)^{\mathrm{a}} \\
5.1 \pm 6.7(36)^{\mathrm{a}}\end{array}$ & $\begin{array}{l}1.81 \pm 2.01(27)^{\mathrm{a}} \\
1.61 \pm 0.84(27)^{\mathrm{a}}\end{array}$ & $\begin{array}{l}0.055 \pm 0.111(36)^{\mathrm{a}} \\
0.032 \pm 0.122(36)\end{array}$ \\
\hline Summer & $\begin{array}{l}\text { Day } \\
\text { Night }\end{array}$ & $\begin{array}{l}-24.8 \pm 18.8(27)^{*} \\
-33.8 \pm 14.3(27)^{*}\end{array}$ & $\begin{array}{l}34.2 \pm 25.6(26)^{\mathrm{a}} \\
51.0 \pm 33.2(27)^{\mathrm{a}}\end{array}$ & $\begin{array}{c}6.8 \pm 12.7(26)^{\mathrm{a}} \\
12.8 \pm 14.3(27)^{\mathrm{a}}\end{array}$ & $\begin{array}{l}2.50 \pm 1.71(27)^{\mathrm{a}} \\
2.67 \pm 1.79(27)^{\mathrm{a}}\end{array}$ & $\begin{array}{l}0.175 \pm 0.361(27)^{\mathrm{a}} \\
0.193 \pm 0.249(27)^{\mathrm{a}}\end{array}$ \\
\hline
\end{tabular}

Table 2. Benthic fluxes (mean $\pm 1 \mathrm{SD}$ ) in San Quintin Bay for the period February 1997 to February 2000 . Values are mmol $\mathrm{m}^{-2} \mathrm{~d}^{-1}$ except TA, which is meq $\mathrm{m}^{-2} \mathrm{~d}^{-1}$. It is assumed that winters and summers are reflected by February and August data, respectively; that the annual average conditions are approximately an average of these $2 \mathrm{mo}$; and that the whole-bay average is represented by the 3 sites. Same abbreviations as Table 1

\begin{tabular}{|c|c|c|c|c|c|}
\hline & $\mathrm{O}_{2}$ & DIC & TA & $\mathrm{NH}_{4}$ & $\mathrm{PO}_{4}$ \\
\hline \multicolumn{6}{|c|}{ Bahia San Quintin (BSQ) } \\
\hline Winter & $-19.3 \pm 7.5$ & $5.0 \pm 16.8$ & $3.9 \pm 5.2$ & $1.50 \pm 1.57$ & $0.047 \pm 0.084$ \\
\hline Summer & $-22.3 \pm 7.9$ & $31.5 \pm 12.6$ & $9.5 \pm 6.2$ & $2.09 \pm 1.03$ & $0.177 \pm 0.135$ \\
\hline Annual & $-20.8 \pm 7.7$ & $18.2 \pm 14.7$ & $6.7 \pm 5.7$ & $1.79 \pm 1.30$ & $0.112 \pm 0.110$ \\
\hline \multicolumn{6}{|c|}{ Bahia Falsa (BF) } \\
\hline Winter & $-12.4 \pm 4.9$ & $17.4 \pm 19.2$ & $5.9 \pm 7.4$ & $1.03 \pm 0.46$ & $-0.005 \pm 0.047$ \\
\hline Summer & $-23.3 \pm 4.7$ & $28.2 \pm 21.7$ & $10.7 \pm 15.0$ & $2.34 \pm 1.50$ & $0.167 \pm 0.245$ \\
\hline Annual & $-17.8 \pm 4.8$ & $22.8 \pm 20.4$ & $8.3 \pm 11.2$ & $1.69 \pm 0.98$ & $0.081 \pm 0.146$ \\
\hline \multicolumn{6}{|c|}{ Base of the Y (BY) } \\
\hline Winter & $-20.6 \pm 8.3$ & $35.4 \pm 14.0$ & $9.6 \pm 4.9$ & $2.60 \pm 1.19$ & $0.088 \pm 0.057$ \\
\hline Summer & $-42.4 \pm 15.5$ & $68.4 \pm 17.3$ & $9.3 \pm 6.7$ & $3.33 \pm 1.64$ & $0.209 \pm 0.251$ \\
\hline Annual & $-31.5 \pm 11.9$ & $51.9 \pm 15.6$ & $9.4 \pm 5.8$ & $2.96 \pm 1.42$ & $0.148 \pm 0.154$ \\
\hline \multicolumn{6}{|c|}{ Whole Bay } \\
\hline Winter & $-17.4 \pm 7.7$ & $19.3 \pm 20.7$ & $6.4 \pm 6.2$ & $1.71 \pm 1.30$ & $0.043 \pm 0.074$ \\
\hline Summer & $-29.3 \pm 13.7$ & $42.7 \pm 25.1$ & $9.8 \pm 9.8$ & $2.59 \pm 1.47$ & $0.184 \pm 0.205$ \\
\hline Annual & $-23.4 \pm 10.7$ & $31.0 \pm 22.9$ & $8.1 \pm 8.0$ & $2.15 \pm 1.39$ & $0.114 \pm 0.140$ \\
\hline
\end{tabular}




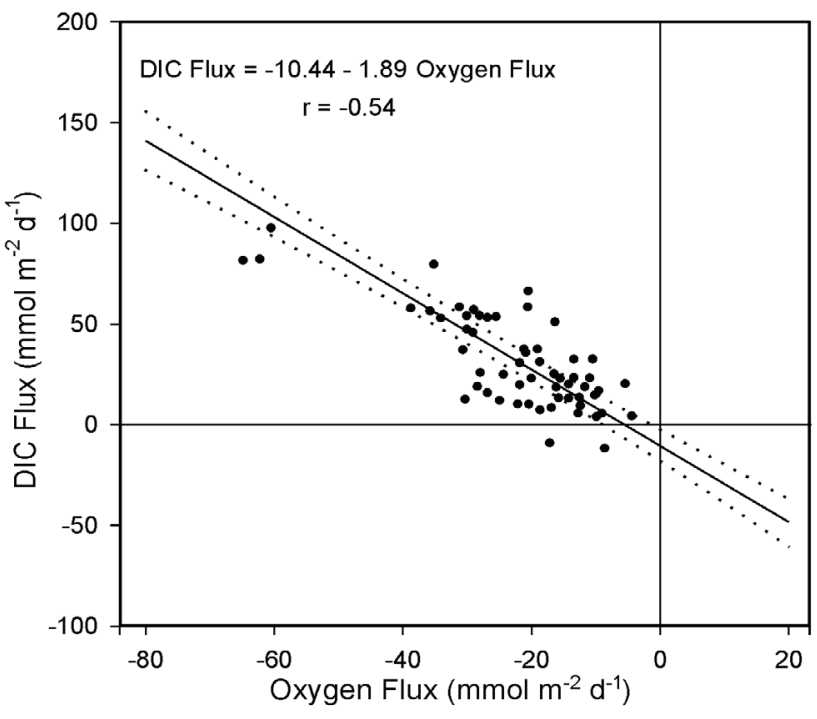

Fig. 3. Scatter diagram of benthic oxygen flux versus DIC flux. Dotted lines represent the $95 \%$ confidence interval

a simple average of the 3 stations as an estimate of whole-bay channel sediment metabolism.

DIC and $\mathrm{O}_{2}$ flux are significantly correlated $(\mathrm{r}=-0.54)$, with a $\mathrm{DIC} / \mathrm{O}_{2}$ flux ratio of about -1.9 determined from the regression slope. This suggests that about half of the net sediment respiration is anaerobic. We recognize that gross respiration in the sediments is likely to be more strongly anaerobic (dominated by sulfate reduction), with subsequent oxidation of sulfide not bound into minerals back to sulfate (see discussion in Smith \& Hollibaugh 1997). Regression analyses of benthic nutrient fluxes show significant, although low, correlation coefficients (Fig. 4). The slopes of regression equations gave the following ratios: the ratio of dissolved inorganic nitrogen to dissolved inorganic phosphate (DIN/DIP) regression slope of $8 \pm 1$ is not significantly different from Redfield N/P (16) ( $p>0.05$ ) (Redfield 1958), because of the low correlation. The slope for DIC/DIN is $20 \pm 2$, about 3 times the Redfield N/P value of 6.6. The slope for DIC/DIP is 136 , or about $30 \%$ above the Redfield value of 106 . Both the $\mathrm{C} / \mathrm{N}$ and $\mathrm{C} / \mathrm{P}$ slopes differ from Redfield $(\mathrm{p}<0.01)$. We believe that the slopes, rather than the average flux ratios, are the

Table 3. Probability values of the 1-tailed $t$-test for benthic flux differences between stations. Probabilities $<0.05$ are statistically significant. Same abbreviations as Table 1

\begin{tabular}{|lccccc|}
\hline Sites & $\mathrm{O}_{2}$ & DIC & $\mathrm{TA}$ & $\mathrm{NH}_{4}$ & $\mathrm{PO}_{4}$ \\
\hline BSQ-BF & 0.130 & 0.366 & 0.565 & 0.806 & 0.478 \\
BF-BY & $<0.001$ & $<0.001$ & 0.578 & 0.008 & 0.202 \\
BSQ-BY & 0.021 & $<0.001$ & 0.090 & 0.016 & 0.436 \\
\hline
\end{tabular}

appropriate metric for comparison with Redfield, because of the clear evidence for DIP sorption. We assume this sorption to be approximately constant and of decreasing importance as the fluxes increase. This process accounts for the significant negative DIP intercepts on Fig. 4. Using Redfield ratios as a reference, benthic $\mathrm{N}$ flux was about $50 \%$ below expectation based on $\mathrm{P}$ and $65 \%$ below expectation based on $\mathrm{C}$. This suggests a sink for regenerated $\mathrm{N}$ with respect to regenerated $\mathrm{C}$ and $\mathrm{P}$. We interpret this sink to be denitrification.

If the reactants leading to the DIP and DIC fluxes are a mixture of plankton (C/P 106) (Redfield 1958) and seagrass ( $\mathrm{C} / \mathrm{P} \sim 550)$ (Atkinson \& Smith 1983), it can be demonstrated from the DIC/DIP flux slope (136) that plankton dominates the reacting organic matter.

\section{Water column metabolism}

Midday $1 \mathrm{~m}{ }^{14} \mathrm{C}$ primary production (PP) averaged $19 \pm 2 \mathrm{mg} \mathrm{m}^{-3} \mathrm{~h}^{-1}$ (mean $\pm \mathrm{SE}$ ) for the 3 sampling sites during August 1999 and $8 \pm 1$ during February 2000 . The mean hourly production/chlorophyll assimilation number for these data was 8.7. A second data set by Montes-Hugo (2001; also Montes-Hugo \& AlvarezBorrego 2003) gave a mean assimilation number of 7.0, so we use a mean assimilation number of 8 for phytoplankton in San Quintin Bay. We apply this value, an extinction coefficient of $0.6 \mathrm{~m}^{-1}$, and mean summer and winter solar radiation values of 2100 and $1500 \mu \mathrm{mol}$ quanta $\mathrm{m}^{-2} \mathrm{~s}^{-1}$ to median summer and winter chlorophyll concentrations throughout this study (4.6 and $1.7 \mathrm{mg} \mathrm{m}^{-3}$, respectively) to calculate PP for the $2 \mathrm{~m}$ water column: $68 \mathrm{mmol} \mathrm{C} \mathrm{m}^{-2} \mathrm{~d}^{-1}$ (summer) and 25 (winter), for an average of $47 \mathrm{mmol} \mathrm{m}^{-2} \mathrm{~d}^{-1}$.

Water column respiration (R) over the period of the study averaged $28 \pm 3 \mathrm{mmol} \mathrm{m}^{-3} \mathrm{~d}^{-1}$ (mean $\pm \mathrm{SE}$ ) during the summer and $25 \pm 2$ during the winter. These rates do not differ, so we use an average rate for the $2 \mathrm{~m}$ water column of $53 \mathrm{mmol} \mathrm{m} \mathrm{m}^{-2} \mathrm{~d}^{-1}$.

$\mathrm{PP}$ and $\mathrm{R}$ rates in the water column are apparently 47 and $53 \mathrm{mmol} \mathrm{m}^{-2} \mathrm{~d}^{-1}$, respectively. While $\mathrm{R}$ apparently slightly exceeds PP, uncertainties in the spatial and temporal distribution of 'independent' variables across the bay, as well as differing analytical methodologies preclude any ability to distinguish between PP and R. We therefore use a value of 50, as the best whole-bay estimate of water column PP and R.

\section{DISCUSSION}

With the exception of phosphate and total alkalinity, higher benthic fluxes appear to occur at BY than at either of the other stations (Tables $2 \& 3$ ). This result is 

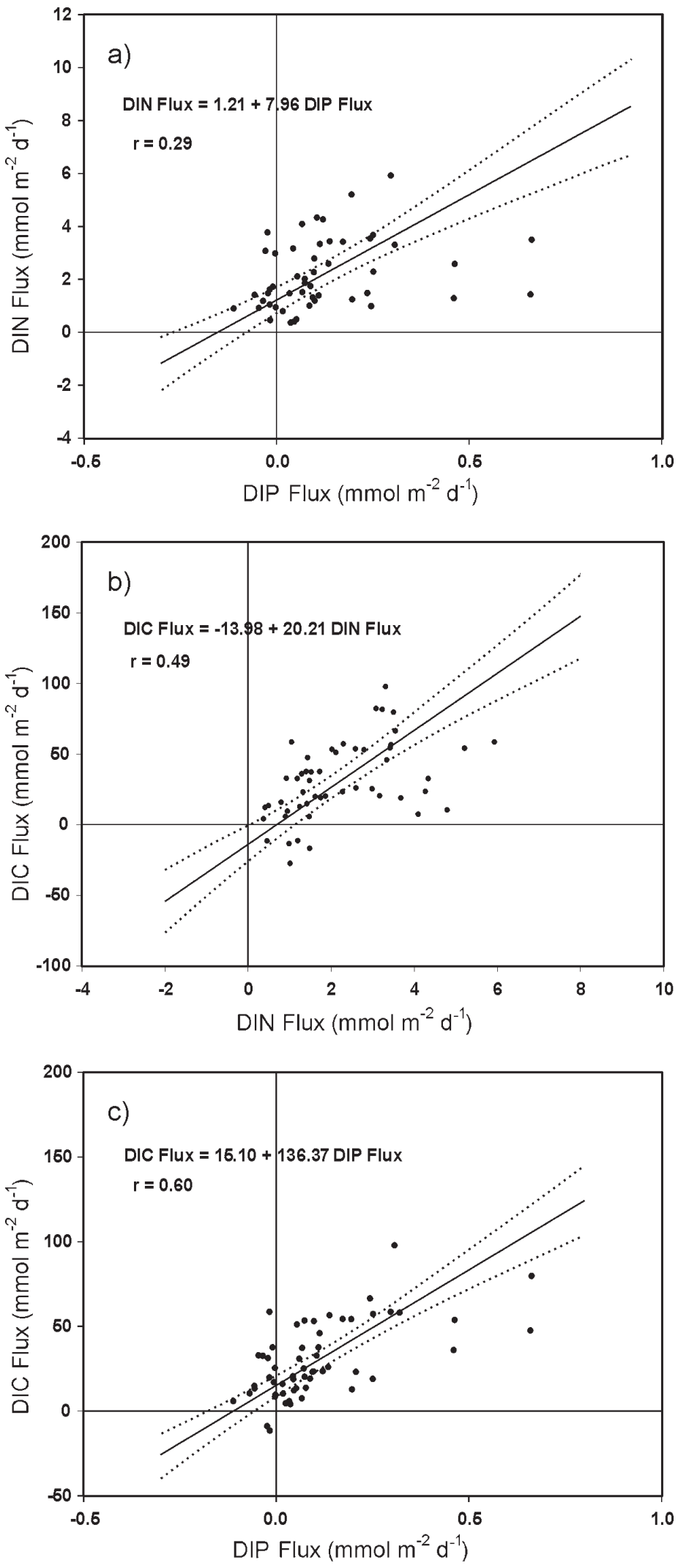

Fig. 4. Regression analysis of benthic fluxes. Dotted lines represent the $95 \%$ confidence interval consistent with the inference of Camacho-Ibar et al. (2003) that marine organic matter is entering the system and much of it is respired near the mouth. However, 3 stations are insufficient to ascertain whether this is truly a spatial pattern or simply variation among these 3 stations. From the C/P flux ratio determined from the regression slope, we conclude that the major source of organic matter on the bottom is planktonic, rather than seagrass detritus. Within the resolution of the data for water column and deep sediment metabolism and our assumptions about fluxes in the other habitats, the only compartment that apparently has $(\mathrm{PP}-\mathrm{R}) \neq 0$ in this system is the deep sediment community.

\section{Gross and net metabolism for bay habitats}

Following the information laid out in 'Study area' description, we consider the following major habitats in the bay (proceeding from the shoreline to the bay bottom): salt marsh, shallow mud flats, seagrass and lagoon bottom muds. In addition, the planktonic community occurs throughout the bay. In this section, we reconcile our data and literature data on primary production and respiration within each habitat, in order to derive baywide 'best estimates' of gross and net metabolism.

\section{Plankton}

While more detailed analysis of the water column metabolism might suggest variations throughout the system, we conclude that water column PP and R are more or less homogeneous throughout the system and approximately equal $\left(\mathrm{PP} \approx \mathrm{R} \approx 50 \mathrm{mmol} \mathrm{m}^{-2} \mathrm{~d}^{-1}\right.$ ).

\section{Salt marsh}

There is a fringe of salt marsh vegetation on much of the coastline of the bay (Fig. 1). While we did not directly measure the salt marsh productivity, we provide estimates for habitat comparisons. From Ward et al. (2003), we estimate that this fringe occupies about $20 \%$ of the bay area. Zedler (1980) has studied PP of rather similar salt marshes in Tijuana Estuary, $300 \mathrm{~km}$ to the northwest of San Quintin. She estimated these marshes to have a PP of approximately $80 \mathrm{mmol} \mathrm{C} \mathrm{m} \mathrm{C}^{-1}$; we use this value for San Quintin. Obvious salt marsh detritus is not found much removed from the habitat itself and there is no evidence of much organic matter accretion in these marshes. We therefore assume that PP largely decomposes in place. Thus $\mathrm{R}$ is also estimated at 
$80 \mathrm{mmol} \mathrm{m}^{-2} \mathrm{~d}^{-1}$. These values for PP and R within the salt marsh habitat can be prorated to give estimates of the salt marsh to bay-wide PP and R: $16 \mathrm{mmol} \mathrm{m}^{-2} \mathrm{~d}^{-1}$ (Table 4).

\section{Shallow mud flats}

We have also not analyzed the metabolism of the shallow mud flats, which also occupy about $20 \%$ of the bay area. We have considered this metabolism from 2 general approaches. (1) We consider the growing base of literature on the PP of microphytobenthos populating estuarine mud flats. (2) We consider some model results which we thought were a promising tool. It can be seen in Fig. 5 that, while there is a wide range in estimated rates of PP in these environments, there is a strong mode between 30 and $100 \mathrm{mmol} \mathrm{m}^{-2} \mathrm{~d}^{-1}$ and a median value of about 20 (http://ecologia.cicese.mx/ sibarra). These data include both intertidal and subtidal sites, with no significant difference in the median.

The second approach we considered was to model the microphytobenthos productivity from sediment chlorophyll (average $\sim 70 \mathrm{mg} \mathrm{m}^{-2}$; Ibarra-Obando \& Elguea-Cazares 1987 - note that in this reference, the chlorophyll units in the text are wrong; units from the figures should be used). Available light and light extinction data are discussed above, for the plankton PP. The model we employed is adapted from Webster et al. (2002) for microphytobenthos and is structurally similar to the model employed for the plankton. This model gives a PP in excess of $300 \mathrm{mmol} \mathrm{m} \mathrm{m}^{-2} \mathrm{~d}^{-1}$ for benthic microalgae living in a mean water depth of $1 \mathrm{~m}$. While we believe that such a model has promise, we are skeptical of the results. This value is above any of the values available in the literature, even though the chlorophyll content of the sediment is apparently reasonable. Further, it seems unlikely that this habitat

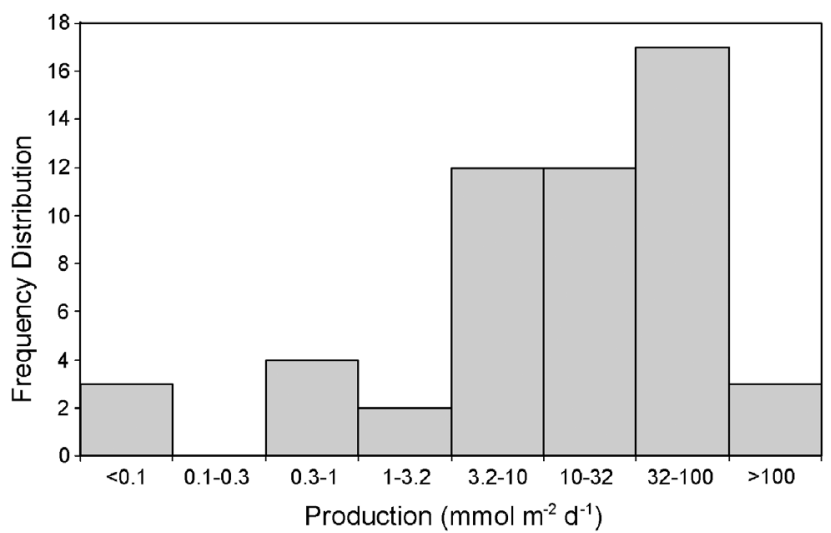

Fig. 5. Frequency distribution of microphytobenthos primary production (PP) $\left(\mathrm{mmol} \mathrm{m} \mathrm{m}^{-2} \mathrm{~d}^{-1}\right)$. Data were obtained from the literature and can be found at http://ecologia. cicese. $\mathrm{mx} / \sim$ sibarra

would have a productivity higher than the highbiomass seagrass habitat. Finally, we note that 2 of the 3 highest values for microphytobenthos PP illustrated in Fig. 5 were derived by Webster et al. (2002) from their model.

We suspect that there may be significant problems with assessing the light actually available for the algal community living in the sediment. We will return to this point below, when discussing the lagoon bottom sediment metabolism. In the end, we conclude that the best estimate of mud flat microphytobenthos PP is the median value cited above $\left(20 \mathrm{mmol} \mathrm{m} \mathrm{m}^{-2} \mathrm{~d}^{-1}\right)$. We further assume that any of these production products that become re-suspended would be trapped (filtered) by the adjacent seagrass and are unlikely to move far from the production sites. As argued for the salt marsh, the lack of rapid sediment organic $\mathrm{C}$ accumulation argues that PP and $\mathrm{R}$ would be similar. Prorated to a bay wide rate, mud flat $\mathrm{PP}$ and $\mathrm{R}$ are each estimated to be about $4 \mathrm{mmol} \mathrm{m}^{-2} \mathrm{~d}^{-1}$ (Table 4 ).
Table 4. Contribution of benthic and water column processes to total system metabolism. Whole bay data for the period August 1998 to February 2000 were used. Primary production (PP) and respiration (R) per unit area of cover for each habitat were multiplied by habitat proportion cover to derive bay-wide rates $\left(\mathrm{mmol} \mathrm{C} \mathrm{m} \mathrm{m}^{-2} \mathrm{~d}^{-1}\right)$

\begin{tabular}{|c|c|c|c|c|c|c|c|}
\hline \multirow{2}{*}{ Habitat } & \multicolumn{3}{|c|}{ Rate within habitat } & \multirow{2}{*}{$\begin{array}{l}\% \text { of area } \\
\text { covered }\end{array}$} & \multicolumn{3}{|c|}{ Bay-wide rate } \\
\hline & PP & $\mathrm{R}$ & $(\mathrm{PP}-\mathrm{R})$ & & $\mathrm{PP}$ & $\mathrm{R}$ & $(\mathrm{PP}-\mathrm{R})$ \\
\hline Salt marsh & 80 & 80 & 0 & $20^{\mathrm{a}}$ & 16 & 16 & 0 \\
\hline Shallow sediment & 20 & 20 & 0 & $20^{\mathrm{a}}$ & 4 & 4 & 0 \\
\hline Seagrass & 230 & 230 & 0 & $40^{\mathrm{a}}$ & 92 & 92 & 0 \\
\hline Deep sediment & $\sim 10$ & 40 & -30 & $20^{\mathrm{a}}$ & 2 & 8 & -6 \\
\hline Total benthos & & & & 100 & 114 & 120 & -6 \\
\hline Water column & 50 & 50 & $\mathbf{0}$ & 100 & 50 & 50 & $\mathbf{0}$ \\
\hline BAY TOTAL & & & & & 164 & 170 & -6 \\
\hline${ }^{\mathrm{a}}$ Rounded from Wa & rd et & $(20$ & & & & & \\
\hline
\end{tabular}

\section{Seagrass}

Marine macrophytic vegetation is the structurally dominant habitat in San Quintin Bay, covering approximately $40 \%$ of the bay area (Ward et al. 2003). The marine vegetation of San Quintin Bay consists mainly of eelgrass Zostera marina best developed in the middle parts of the bay on flats that are covered by 0.3 to $0.9 \mathrm{~m}$ of water at the lowest tide. Ibarra-Obando \& Huerta-Tamayo (1987) reported a range for eelgrass PP between 60 and $410 \mathrm{mmol} \mathrm{C} \mathrm{m} \mathrm{C} \mathrm{d}^{-1}$. The mean was about $230 \mathrm{mmol} \mathrm{C} \mathrm{m} \mathrm{m}^{-2} \mathrm{~d}^{-1}$ in 
the seagrass area; weighted across the entire bay, this is equivalent to about $92 \mathrm{mmol} \mathrm{C} \mathrm{m} \mathrm{m}^{-2}$. Some, but relatively little, seagrass detritus is found on the bay floor, so we again assume that most of the R occurs more or less in situ. This observation is consistent with the conclusion (above) that most sediment $\mathrm{R}$ is apparently detrital material.

\section{Lagoon bottom sediments}

Finally we come to lagoon bottom metabolism, the focus of this investigation. From Table 2, we conclude that metabolism on the lagoon bottom averages approximately $+30 \mathrm{mmol} \mathrm{m}^{-2} \mathrm{~d}^{-1}$, based on the DIC flux data. This represents net metabolism based on $24 \mathrm{~h}$ incubations. From Table 1, day versus night DIC flux data (summer + winter), we estimate that daytime flux is about $10 \mathrm{mmol} \mathrm{m}^{-2} \mathrm{~d}^{-1}$ slower than nighttime flux, implying that microphytobenthos PP on the bay floor is about this value. The $\mathrm{O}_{2}$ flux difference between the day and night is not statistically significant but gives an average difference similar to the DIC flux data. It follows that gross $\mathrm{R}$ is about $40 \mathrm{mmol} \mathrm{m}^{-2} \mathrm{~d}^{-1}$. These observations can be compared with the microphytobenthos PP model discussed above. The same model gives PP estimates in excess of $200 \mathrm{mmol} \mathrm{m}^{-2} \mathrm{~d}^{-1}$ for the channel floor, again apparently too high for the reasons previously discussed and also inconsistent with the observed fluxes in the incubation chambers.

The deep lagoon channel sediments occupy about $20 \%$ of the bay area, so the baywide levels of PP and R are estimated to be 2 and $8 \mathrm{mmol} \mathrm{m} \mathrm{m}^{-2} \mathrm{~d}^{-1}$, respectively (Table 4). It is worth noting that, unlike the other habitats, we estimate the net metabolism for the lagoon floor clearly differs from 0 . Within both our ability to distinguish and our judgment, we assign all of the net metabolic signal of this system to the deep channel sediments.

\section{Whole-bay gross and net metabolism}

Measurement or estimation of the components of gross metabolism in San Quintin Bay allows us to assess the relative importance of benthic and water column metabolic pathways. As Kemp et al. (1997) concluded, partitioning of overall rates among individual processes allows the description of temporal and spatial patterns. Preliminary estimates of gross metabolism for San Quintin Bay were performed by Smith \& Ibarra-Obando (1997) and Camacho-Ibar et al. (2003). We also compared San Quintin gross metabolism with Tomales Bay, determined by Smith \& Hollibaugh (1997) with very similar methodologies. It can be seen that in all cases, $(\mathrm{PP}-\mathrm{R})$ has values close to zero, hence that $\mathrm{PP} / \mathrm{R}$ is within about $10 \%$ of 1 (Table 5 ).

Smith \& Hollibaugh (1993) noted that, for most ecosystems, PP and R are within 10-20\% of one another. As a consequence of both statistical uncertainties and methodological differences between measurements for the various components of total system metabolism, it becomes difficult to quantify NEP (Net Ecosystem Production) by 'adding the parts' (Smith \& Hollibaugh 1993, 1997). Indeed, when we compare net ecosystem metabolism obtained by summation of the parts (Table 4), with net metabolism at the ecosystem level obtained through the use of nutrient budgets (Camacho-Ibar et al. 2003), our estimate of net heterotrophy represents an apparent underestimate (Table 5). For San Quintin Bay, both adding the parts and direct, whole-system estimates of net metabolism yield NEP < 0 (net heterotrophy). Tomales Bay seems to have NEP slightly $>0$ when the parts are added, but a negative value with the direct whole-system net estimates (Table 5). We believe (as did Smith \& Hollibaugh $1993,1997)$ that the discrepancy reflects a propagation of uncertainties when the component fluxes are summed, and that adding the component fluxes rarely can give a reliable estimate of NEP.

Table 5. Comparison of gross and net metabolism between San Quintin Bay, Baja California, Mexico and Tomales Bay, California, USA, expressed in mmol C m${ }^{-2} \mathrm{~d}^{-1}$. The 'summed gross' method adds up primary production (PP) and respiration (R) for major habitats, while the 'system net' method uses the hydrographically calculated DIP budget normalized to carbon as an estimate of $(\mathrm{PP}-\mathrm{R})$. The 'combination method' reports the average of gross PP and R as PP, system net as (PP - R) and calculates R by difference. The combination values shown in bold type are considered to be the best estimates for San Quintin and Tomales Bays, respectively

\begin{tabular}{|llccccl|}
\hline Location & Method & PP & R & (PP - R) & PP/R & Source \\
\hline San Quintin Bay & Summed gross & 199 & 209 & -10 & 0.95 & Smith \& Ibarra-Obando (1997) \\
& Net and combination & 185 & 200 & -14 & 0.93 & Camacho-Ibar et al. (2003) \\
& Summed gross & 164 & 170 & -6 & 0.96 & This study \\
& Combination & $\sim \mathbf{1 6 7}$ & $\sim \mathbf{1 8 1}$ & $\mathbf{- 1 4}$ & $\sim \mathbf{0 . 9 2}$ & Gross from this study, Camacho-Ibar (2003) \\
Tomales Bay & Summed gross & 110 & 105 & +5 & 1.05 & Smith \& Hollibaugh (1997) \\
& System net & & & -12 & & Smith \& Hollibaugh (1997) \\
& Combination & $\mathbf{1 0 1}$ & $\mathbf{1 1 3}$ & $\mathbf{- 1 2}$ & $\mathbf{\sim 0 . 8 9}$ & Smith \& Hollibaugh (1997) \\
\hline
\end{tabular}


For both Tomales and San Quintin bays, we have combined an 'average estimate' of PP and R, with a system-level estimate of NEP to derive a 'best estimate' of $\mathrm{PP}, \mathrm{R},(\mathrm{PP}-\mathrm{R})$ and $\mathrm{PP} / \mathrm{R}$ (Table 5).

Our values for benthic $\mathrm{O}_{2}$ and particularly DIC fluxes in San Quintin Bay are highest at Station BY (Tables 2 \& $3)$. This result is consistent with the pattern of net metabolism reported by Camacho-Ibar et al. (2003), who calculated the highest rates, $-45 \mathrm{mmol} \mathrm{C} \mathrm{m} \mathrm{m}^{-2} \mathrm{~d}^{-1}$, near the mouth (station BY) during summer. They considered the possibility that higher community R at this site could be responsible for this condition. Heterotrophy is now recognized as a common trend in coastal lagoons and estuaries (e.g. Smith \& Hollibaugh 1993, Frankignoulle et al. 1998), with the timing of heterotrophy through the year providing clues to the sources of organic matter that sustains metabolic activity (Hopkinson 1985).

Although not statistically significant, phosphate flux in our study seems to follow the same spatial trend reported by Camacho-Ibar et al. (2003), with higher values at the base of the Y (BY). Anomalously low N/P flux ratios, relative to organic matter composition, have been reported for virtually all coastal waters (Nixon 1981). The interpretation placed on this ratio (Nixon 1981, Dollar et al. 1991 and related studies of Tomales Bay) has been that the 'missing N' has been lost to denitrification. While this may break down in the winter, when fluxes are low and sorption may be of importance to the phosphorus flux (Joye et al. 1996), this latter effect seems to be small when integrated over an annual cycle (Smith \& Hollibaugh 1997). Stoichiometric calculations based on the median and mean DIP and DIN fluxes are shown in Fig. $6 \mathrm{~b}$, and suggest that 40 to $60 \%$ of the DIN release during oxidation in shallow marine sediments is lost to denitrification. These results are comparable to estimates based on denitrification assays (e.g. Seitzinger 1988).

\section{Benthic fluxes in comparison to literature data}

For each flux examined, San Quintin falls near the median of values reported for other systems. Nothing suggests the benthic metabolism for this system to differ from most shallow benthic systems (Fig. 6). The fact that $\mathrm{NO}_{3}$ fluxes were not measured at San Quintin is not a major issue in this analysis, as $\mathrm{NH}_{4}{ }^{+}$is generally the dominant form of dissolved nitrogen flux in shallow ecosystems (compare Fig. 6b \& 6c).

\section{Benthic-pelagic coupling}

Benthic and planktonic metabolism were compared during this study (Table 4). It can be noted that benthic processes dominate the metabolism at the system level. Among the benthic components and within the limits of our assumptions, seagrass beds are responsible for about $70 \%$ of the PP and R in the bay. Using the baywide $\mathrm{PP}$ and $\mathrm{R}$ values in Table 5, we obtain an ecosystem $\mathrm{PP} / \mathrm{R}$ ratio of about 0.9 . About $10 \%$ of the organic matter respired in this system apparently comes from outside the system. Vertical fluxes from the water column to the deep bay sediments couple organic carbon, nitrogen and phosphorus fluxes, to balance the excess benthic R over PP (Smith et al. 1981).

Nixon (1981) analyzed the benthic-pelagic coupling in diverse estuarine systems, converting the reported oxygen uptake measurements to carbon, by using an $\mathrm{RQ}$ of 1 . He concluded that benthic $\mathrm{R}$ represented about $24 \%$ of the amount of organic matter fixed plus that imported. Dollar et al. (1991) did a similar analysis and added 9 more sites, including Tomales Bay, and they arrived at a rather different conclusion: Tomales Bay sediments respired about $25 \%$ of PP based on DIC flux, close to Nixon's general prediction based on $\mathrm{O}_{2}$. However, the sediment $\mathrm{O}_{2}$ flux in Tomales only accounted for about $15 \%$ of the PP. Almost half of the sediment metabolism apparently was anaerobic respiration that did not subsequently back-react with $\mathrm{O}_{2}$. We updated this analysis with a larger database using the following criteria to exclude references: (1) sites deeper than 20 m, (2) laboratory experiments, (3) sites with obviously high organic load other than from PP and (4) sites with salinities well below $10 \mathrm{psu}$. We end up with 21 data points including Tomales Bay and San Quintin Bay. For these 2 locations and South San Francisco Bay, we also have DIC values (Fig. 7). With the 21 data points we had $r^{2}=0.38$. If we consider point \#13 as an outlier, $\mathrm{r}^{2}$ becomes 0.60 . As this change has no statistical significance in the slope or intercept, we decided to leave it in and report the regression as $y=0.4 x+4$.

As shown in Figs. 3 \& 7, the discrepancy between $R$ expressed in terms of $\mathrm{O}_{2}$ and DIC, reported by Dollar et al. (1991) for Tomales Bay, can also be seen for San Quintin Bay. With this revised data set, we found that benthic $\mathrm{R}$ calculated from $\mathrm{O}_{2}$ flux represents $40 \%$ of $\mathrm{PP}$, a larger percentage than the one reported by Nixon (1981) (Fig. 7). More importantly, it is clear that both for Tomales and for San Quintin, DIC-based estimates of R are about twice the $\mathrm{O}_{2}$-based estimates.

South San Francisco Bay appears to differ from these 2 cases; there, DIC fluxes are slightly smaller than $\mathrm{O}_{2}$ values (Fig. 7). If a correction of about $50 \%$ could be applied to all the data in Fig. 7, the slope of the line would approach 0.8 . While data from only 2 sites is insufficient to apply the suggested correction quantitatively, it is qualitatively persuasive evidence that benthic $\mathrm{R}$ is likely to dominate total system $\mathrm{R}$ in many such shallow marine systems. In another example, Forja et al. (1994) reported that sediments in Cadiz Bay in 

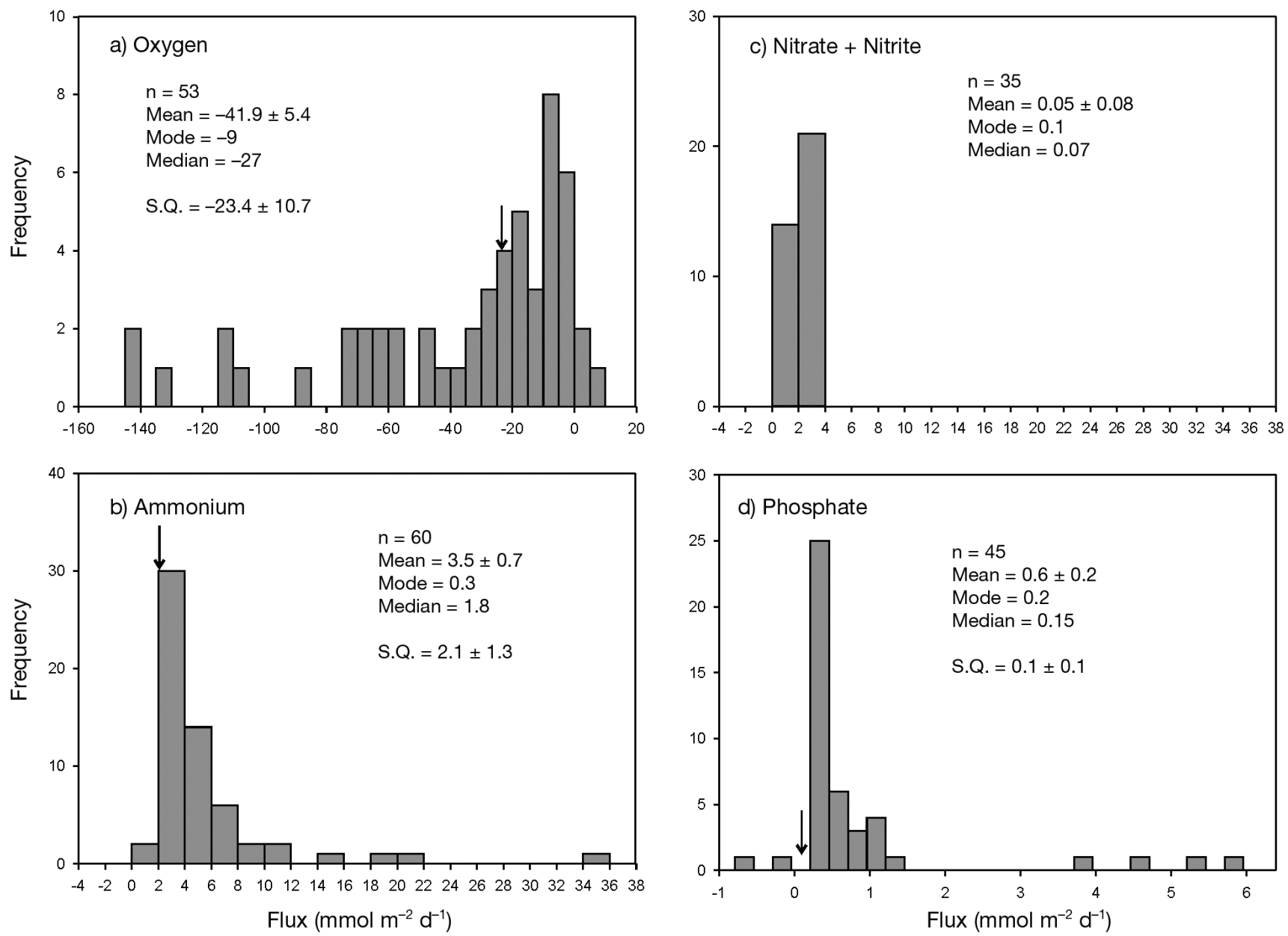

Fig. 6. Histograms showing mean benthic fluxes in shallow marine environments. Values for San Quintin Bay (S.Q. = San Quintin Bay) are indicated with an arrow. (a) Oxygen fluxes; (b) ammonium fluxes; (c) nitrate fluxes. We do not have flux value for S.Q. Bay, but it is likely to be low with respect to $\mathrm{NH}_{4}$ flux; (d) Phosphate fluxes. The data base can be found at http://ecologia. cicese.mx/ sibarra

Spain have much higher alkalinity flux than $\mathrm{O}_{2}$ flux. This study was excluded from the plot in Fig. 7, because the system apparently receives heavy loading from sewage organic matter. While the data cannot be directly converted to DIC fluxes, the high values for alkalinity flux imply that DIC flux substantially exceeds $\mathrm{O}_{2}$ flux.

\section{Comparison between San Quintin and Tomales Bays}

San Quintin Bay and Tomales Bay are under rather similar hydrographic and weather regimes due to the presence of upwelling and classical Mediterranean climate (cool, wet winters; hot, dry summers) (Smith \& Hollibaugh 1997, Aguirre-Muñoz et al. 2001). The primary difference is the absence of runoff into San Quintin compared to low, but significant, runoff into Tomales. Both systems are light-limited because of high turbidity and both have plankton as impor- tant primary producers (Lara-Lara \& Alvarez-Borrego 1975, Cole 1989, Cabello-Pasini et al. 2003). They also have prominent seagrass (Zostera marina) beds (Spratt 1989, Poumian-Tapia \& Ibarra-Obando 1999) and a rather similar benthic fauna (Johnson 1970, SinicropeTalley et al. 2000).

Both sites are important for mollusk aquaculture (mainly oyster). The human modification of the overall San Quintin catchment has been small, in terms of impacts on San Quintin Bay, although the lower part of the catchment has been intensively cultivated (Aguirre-Muñoz et al. 2001). Because rainfall is low (average $=150 \mathrm{~mm} \mathrm{yr}^{-1}$ ), there is no runoff during most years, and agricultural and domestic sewage discharges do not reach the bay. For Tomales Bay, a similar low level of watershed modification exists, although a major difference is the higher precipitation rate, $950 \mathrm{~mm} \mathrm{yr}^{-1}$, with an average runoff, normalized to the bay area, of $300 \mathrm{~mm} \mathrm{~d}^{-1}$ (Smith \& Hollibaugh 1997). Human population density is low in both areas: 


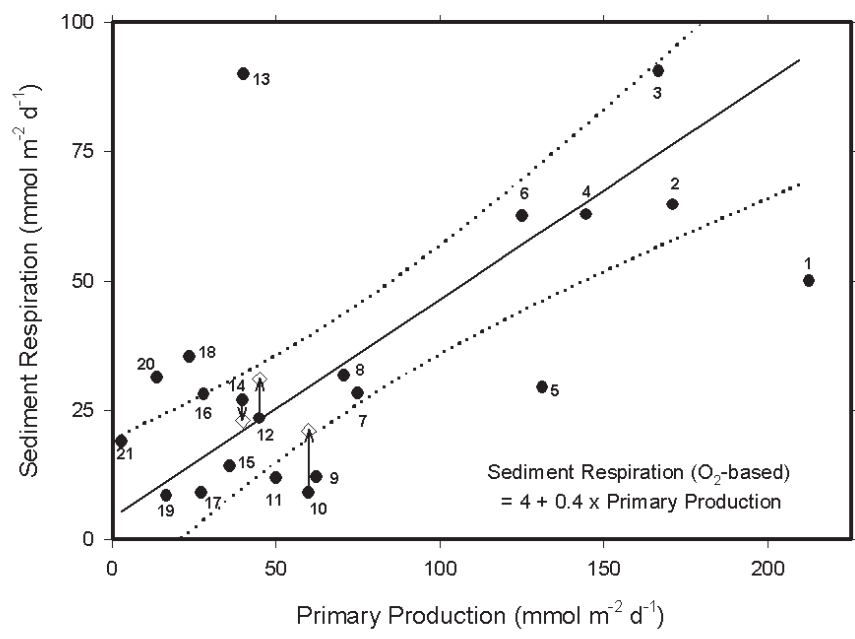

Fig. 7. Scatter diagram of pelagic water column primary productivity (PP) versus sediment respiration $(\mathrm{R})$ in coastal environments $(<20 \mathrm{~m}$ deep). All sediment $\mathrm{R}$ values are expressed as $\mathrm{O}_{2}$ fluxes (black symbols), except for the 3 explicitly identified as DIC fluxes (empty symbols) for San Quintin Bay, Tomales Bay and South San Francisco Bay. Sources and sites: (1) Kemp \& Boynton (1980), Calvert Cliffs, Chesapeake Bay, Maryland, USA; (2) Hopkinson (1985), Georgia Bight, Georgia, USA; (3) Hopkinson \& Wetzel (1982); Thomas (1966), Sapelo Island, Georgia, USA; (4) Boynton \& Kemp (1985), Chesapeake Bay, Maryland, USA; (5) Kemp et al. (1992), Chesapeake Bay, Maryland, USA; (6) Boynton et al. (1980), Patuxtent Estuary, Maryland, USA; (7) Hartwig (1978); Eppley et al. (1970); La Jolla, California, USA; (8) Furnas et al. (1976); Nixon et al. (1976), Narragansett Bay, Rhode Island, USA; (9) Pollehne (1986); Bodungen (1975), Kiel Bight, Germany; (10) Dollar et al. (1991), Tomales Bay, California, USA; (11) Bulleid (1984); Cuff et al. (1983), Port Hacking Estuary, Australia; (12) This study, San Quintin Bay, Baja California, Mexico; (13) Flint \& Kamykoski (1984), Port Aransas, Texas, USA; (14) Hammond et al. (1985); Cloern et al. (1985), South San Francisco Bay, California, USA; (15) Smith et al. (1981), Kaneohe Bay, Hawaiian Is. USA, post diversion conditions; (16) Seitzinger (1987); Myers \& Iverson (1981), Ochlockonee Bay, Florida, USA; (17) Nowicki \& Nixon (1985 a, 1985b), Potter Pond lagoon, Rhode Island, USA; (18) Florek \& Rowe (1983), New York Bight, Massachusetts, USA; (19) Smith et al. (1981), Kaneohe Bay, Hawaiian Is., USA, pre diversion conditions; (20) Rizzo (1990), York River, Gloucester Point, Virginia USA; (21) Knoppers et al. (1996), Ararama lagoon, Brazil. Dotted lines are $95 \%$ confidence interval

$\sim 20$ persons $\mathrm{km}^{-2}$ in the catchment of Tomales Bay (Smith \& Hollibaugh 1997) and 13 persons $\mathrm{km}^{-2}$ in San Quintin Valley (Aguirre-Muñoz et al. 2001).

When compared with similar methodology, it becomes evident that the metabolic performance of the 2 systems is rather similar. Our study exemplifies how a regional perspective can be developed, when sites are compared using the same methodology. This regional perspective is necessary in order to characterize the relationship of nutrient fluxes to environmental change, including human intervention (Holligan \& Reiners 1992).

\section{Summary}

The analysis of benthic fluxes indicated that in San Quintin Bay, about half of sediment respiration is anaerobic and that the major source of organic matter respired on the lagoon floor is planktonic, rather than seagrass detritus. Values for benthic fluxes in San Quintin are similar to those described for most shallow benthic systems. Benthic processes dominate the metabolism at the system level, accounting for approximately $70 \%$ of total PP and R. Seagrass accounts for about $80 \%$ of benthic metabolism. Using an extensive data base for shallow systems, we found that benthic $\mathrm{R}$ calculated from $\mathrm{O}_{2}$ flux represents about $40 \%$ of PP. DIC-based estimates of $\mathrm{R}$ for Tomales and for San Quintin are almost twice the $\mathrm{O}_{2}$-based estimates, providing evidence that sediment respiration is likely to dominate total system respiration in shallow marine systems.

Acknowledgements. We thank the divers F. Becerril and J. L. Pech for their help installing the domes, SCRIPPS Institution of Oceanography for reading our ${ }^{14} \mathrm{C}$ samples, F. Ponce and J.M. Domínguez for the figures, and D. Sarracino for her help locating references. Comments of 2 anonymous reviewers helped improve the manuscript. This study was funded by CONACYT, through grant No. 25030-T to S.E.I-O.

\section{LITERATURE CITED}

Aguirre-Muñoz A, Buddemeier RW, Camacho-Ibar V, Carriquiry JD, Ibarra-Obando SE, Massey, BW, Smith SV, Wulff F (2001) Sustainability of coastal resources in San Quintin, Mexico. Ambio 30:142-149

Atkinson MJ, Smith SV (1983) C: N: P ratios of benthic marine plants. Limnol Oceanogr 28:568-574

Boynton WR, Kemp WM (1985) Nutrient regeneration and oxygen consumption by sediments along an estuarine salinity gradient. Mar Ecol Prog Ser 23:45-55

Boynton WR, Kemp WM, Osborne CG (1980) Nutrient fluxes across the sediment-water interface in the turbid zone of a coastal plain estuary. In: Kennedy VS (ed) Estuarine perspectives. Academic Press, New York, p 93-109

Boynton WR, Hagy JD, Murray L, Stokes C, Kemp WM (1996) A comparative analysis of eutrophication patterns in a temperate coastal lagoon. Estuaries 19:408-421

Bulleid NC (1984) Deoxygenation and remineralization above the sediment-water interface; an in situ experimental study. Estuar Coast Shelf Sci 19:15-25

Cabello-Pasini A, Muñiz-Salazar R, Ward DH (2003). Annual variations of biomass and photosynthesis in Zostera marina at its southern end of distribution in the North Pacific. Aquat Bot 76:31-47

Camacho-Ibar VF, Carriquiry JD, Smith SV (1999) Bahia San Quintin, Baja California: N/P budgets within compartments in a coastal lagoon. In: Smith SV, Marshall Crossland JI, Crossland CJ (eds) Mexican and Central American coastal lagoon systems: carbon, nitrogen and phosphorus fluxes (Regional Workshop II). LOICZ Reports \& Studies No. 13, LOICZ IPO, Texel, p 65-78

Camacho-Ibar VF, Carriquiry JD, Smith SV (2003) Non- 
conservative $\mathrm{P}$ and $\mathrm{N}$ fluxes and net ecosystem production in San Quintin Bay, Mexico. Estuaries 26:1220-1237

Cloern JE, Cole BE, Wong RLJ, Alpine AE (1985) Temporal dynamics of estuarine phytoplankton: a case study of San Francisco Bay. Hydrobiologia 129:177-197

Cole BE (1989) Temporal and spatial patterns of phytoplankton production in Tomales Bay. Estuar Coast Shelf Sci 28: 103-115

Cuff WR, Sinclair RE, Parker RR, Tranter DJ and 8 others (1983) A carbon budget for South West Arm, Port Hacking. In: Cuff W, Tomczak M Jr (eds) Synthesis and modeling of intermittent estuaries: a case study from planning to evaluation. Springer, New York

D'Avanzo CD, Kremer JN, Wainright SC (1996) Ecosystem production and respiration in response to eutrophication in shallow temperate estuaries. Mar Ecol Prog Ser 141: 263-274

Dollar SJ, Smith SV, Vink SM, Obrebski S, Hollibaugh, JT (1991) Annual cycle of benthic nutrient fluxes in Tomales Bay, California, and contribution of the benthos to total ecosystem metabolism. Mar Ecol Prog Ser 79:115-125

Eppley RW, Reid FMH, Strickland JDH (1970) The ecology of the plankton off La Jolla, California, in the period April through September, 1967. Part III. Bull Scripps Inst Oceanogr 17:33-42

Flint RW, Kamykowski D (1984) Benthic nutrient regeneration in South Texas coastal waters. Estuar Coast Shelf Sci 18: 221-230

Florek RJ, Rowe GT (1983) Oxygen consumption and dissolved inorganic nutrient production in marine coastal and shelf sediments of the Middle Atlantic Bight. Int Rev Gesamten Hydrobiol 68:73-112

Forja JM, Blasco J, Gómez-Parra A (1994) Spatial and seasonal variation of in situ benthic fluxes in the Bay of Cadiz (South-west Spain). Estuar Coast Shelf Sci 39:127-141

Fourqurean JW, Webb KL, Hollibaugh JT, Smith SV (1997) Contributions of the plankton community to ecosystem respiration, Tomales Bay, California. Estuar Coast Shelf Sci 44:493-505

Frankignoulle MG, Abril A, Borges I, Bourge C, Canon B, Delille EL, Théat JM (1998) Carbon dioxide emissions from European estuaries. Science 282:434-436

Furnas MJ, Hitchcock GL, Smayda TJ (1976) Nutrientphytoplankton relationships in Narragansett during the 1974 summer bloom. In: Wiley ML (ed) Estuarine processes I: uses, stresses, and adaptations to the estuary. Academic Press, New York, p 118-133

Giblin AE, Hopkinson CS, Tucker J (1997) Benthic metabolism and nutrient cycling in Boston Harbor, Massachusetts. Estuaries 20:346-364

Hammond DE, Fuller C, Harmon D, Hartman B and 6 others (1985) Benthic fluxes in San Francisco Bay. Hydrobiologia 129:69-70

Hargrave BT (1973) Coupling carbon flow through some pelagic and benthic communities. J Fish Res Board Can 30:1317-1326

Hartwig EO (1978) Factors affecting respiration and photosynthesis by the benthic community of a subtidal siliceous sediment. Mar Biol 46:283-293

Holligan PM, Reiners WA (1992) Predicting the responses of the coastal zone to global change. Adv Ecol Res 22:211-255

Hopkinson CS Jr (1985) Shallow-water benthic and pelagic metabolism: evidence of heterotrophy in the nearshore Georgia Bight. Mar Biol 87:19-32

Hopkinson CS, Wetzel RL (1982) In situ measurements of nutrient and oxygen fluxes in a coastal marine benthic community. Mar Ecol Prog Ser 10:29-35
Ibarra-Obando SE, Elguea-Cázares G (1987) Benthic microflora biomass on a lagoon of the west coast of Baja California, Mexico. Cien Mar 13:39-51

Ibarra-Obando SE, Huerta-Tamayo R (1987) Blade production of Zostera marina (L.) during the summer-autumn period on the Pacific coast of Mexico. Aquat Bot 28:301-315

Johnson RG (1970) Variations in diversity within benthic marine communities. Am Nat 104:285-300

Jørgensen BB, Sørensen J (1985) Seasonal cycles of $\mathrm{O}_{2}, \mathrm{NO}_{3}{ }^{-}$ and $\mathrm{SO}_{4}{ }^{2-}$ reduction in estuarine sediments: the significance of an $\mathrm{NO}^{-}$reduction minimum in spring. Mar Ecol Prog Ser 24:65-74

Joye SB, Smith SV, Hollibaugh JT, Paerl HW (1996) Estimating denitrification rates in estuarine sediments: a comparison of stoichiometric and acetylene-based methods. Biogeochemistry 33:197-215

Kemp WM, Boynton WR (1980) Influence of biological and physical factors on dissolved oxygen dynamics in an estuarine system: implications for measurement of community metabolism. Estuar Coast Mar Sci 11:407-431

Kemp WM, Boynton WR (1984) Spatial and temporal coupling of nutrient inputs to estuarine primary production: the role of particulate transport and decomposition. Bull Mar Sci 35:522-535

Kemp WM, Sampou P, Garber J, Tuttle J, Boynton W (1992) Seasonal depletion of oxygen from bottom waters of Chesapeake Bay: roles of benthic and pelagic respiration and physical exchange. Mar Ecol Prog Ser 85:137-152

Kemp WM, Smith EM, Marvin-Di Pasquale M, Boynton WR (1997) Organic carbon balance and net ecosystem metabolism in Chesapeake Bay. Mar Ecol Prog Ser 150:229-248

Knoppers B, Landim-de-Souza FL, Landim-de-Souza MF, Gonzalez-Rodriguez E, Viana-Landim EF, RomanazziVieira A (1996) In situ measurements of benthic primary production, respiration and nutrient fluxes in a hypersaline coastal algoon of SE Brazil. Rev Bras Oceanogr 44: 155-165

Lara-Lara JR, Alvarez-Borrego S (1975) Ciclo anual de clorofilas y producción orgánica primaria en Bahía San Quintín, B.C. Cien Mar 2:77-97

Largier JL, Hollibaugh JT, Smith SV (1997) Seasonally hypersaline estuaries in Mediterranean-climate regions. Estuar Coast Shelf Sci 45:789-797

Montes-Hugo MA (2001) Modelización de la producción primaria fitoplanctónica en sistemas costeros. PhD thesis, Centro de Investigación Científica y de Educación Superior de Ensenada

Montes-Hugo MA, Alvarez Borrego S (2003) Spatial and temporal variation of photosynthetic parameters of phytoplankton in a subtropical coastal lagoon. Estuar Coast Shelf Sci 56:516-526

Myers VB, Iverson RI (1981) Phosphorus and nitrogen limited phytoplankton productivity in northeastern Gulf of Mexico coastal estuaries. In: Neilson BJ, Cronin LE (eds) Estuaries and nutrients. Humana Press, Clifton, NJ, p 569-582

Nixon SW (1981) Remineralization and nutrient cycling in coastal marine ecosystems. In: Nielson BJ, Cronin LE (eds) Estuaries and nutrients. Humana Press, Clifton, NJ, p 111-138

Nixon SW, Oviatt CA, Hale SS (1976) Nitrogen regeneration and the metabolism of coastal marine bottom communities. In: Anderson JM, Macfadyen A (eds) The role of terrestrial and aquatic organisms in decomposition processes. 17th Symp Brit Ecol Soc. Blackwell Scientific, Oxford, p 269-283

Nixon SW, Pilson MEQ (1984) Estuarine total system metabolism and organic exchange calculated from nutrient 
ratios: an example from Narragansett Bay, p 261-290. In: Kennedy VS (ed) The estuary as a filter. Academic Press, New York

Nowicki BL, Nixon SW (1985a) Benthic community metabolism in a coastal lagoon ecosystem. Mar Ecol Prog Ser 22:21-30

Nowicki BL, Nixon SW (1985b) Benthic nutrient remineralization in a coastal lagoon ecosystem. Estuaries 8:182-190

Pollehne F (1986) Benthic nutrient regeneration processes in different sediment types of Kiel Bight. Ophelia 26: 359-368

Poumian-Tapia M, Ibarra-Obando SE (1999) Demography and biomass of the seagrass Zostera marina in a Mexican coastal lagoon. Estuaries 22:879-889

Redfield AC (1958) The biological control of chemical factors in the environment. Am Sci 46:205-221

Ricker WE (1973) Linear regressions in fishery research. J Fish Res Board Can 30:409-434

Rizzo WM (1990) Nutrient exchanges between the water column and a subtidal benthic microalgal community. Estuaries 13:219-226

Seitzinger SP (1987) Nitrogen biogeochemistry in an unpolluted estuary: the importance of benthic denitrification. Mar Ecol Prog Ser 41:177-186

Seitzinger SP (1988) Denitrification in freshwater and coastal marine ecosystems: ecological and geochemical significance. Limnol Oceanogr 33:702-724

Sinicrope-Talley T, Dayton PK, Ibarra-Obando SE (2000) Tidal flat macrofaunal communities and their associated environments in estuaries of Southern California and Northern Baja California, Mexico. Estuaries 23:97-114

Smith SV, Hollibaugh JT (1993) Coastal metabolism and the oceanic organic carbon balance. Rev Geophys 31:75-89

Smith SV, Hollibaugh JT(1997) Annual cycle and interannual variability of ecosystem metabolism in a temperate climate embayment. Ecol Monogr 67:509-533

Smith SV, Ibarra-Obando SE (1997) Comparison of net \&

Editorial responsibility: Otto Kinne (Editor), Oldendorf/Luhe, Germany gross budget for Bahía San Quintín. In: Smith SV, IbarraObando SE, Boudreau PR, Camacho-Ibar VF (eds) Comparison of carbon, nitrogen and phosphorous fluxes in Mexican coastal lagoons. LOICZ Reports \& Studies No. 10, LOICZ, Texel, p 71-73

Smith SV, Kimmerer WJ, Laws EA, Brock RE, Walsh TW (1981) Kaneohe Bay sewage diversion experiment: perspectives on ecosystem response to nutritional perturbation. Pac Sci 35:279-402

Smith SV, Kinsey DW (1978) Calcification and organic carbon metabolism indicated by carbon dioxide. In: Stoddart DR, Johannes RE (eds) UNESCO Monographs on oceanographic methods 5, Coral reefs: research methods, p 469-484

Spratt JD (1989) The distribution and density of eelgrass, Zostera marina, in Tomales Bay, California. Calif Fish Game 75:204-212

Strickland JDH, Parsons TR (1972) A practical handbook of seawater analysis. Fisheries Research Board of Canada, Ottawa

Thomas JP (1966) The influence of the Altamaha River on primary production beyond the mouth of the river. MS thesis, University of Georgia, Athens, GA

Von Bodungen B (1975) Der Jahresgang der Nährsalze und der Primärproduktion des Planktons in der Kieler Bucht unter Berücksichtigung der Hydrographie. PhD thesis, Kiel University

Ward DH, Tibbitts TL, Morton A, Carrera-González E, Kempa $\mathrm{R}$ (2003) Long-term change in eelgrass distribution at Bahía San Quintín, Baja California, Mexico, using satellite imagery. Estuaries 26:1529-1539

Webster IT, Ford PW, Hodgson B (2002) Microphytobenthos contribution to nutrient-phytoplankton dynamics in a shallow coastal lagoon. Estuaries 25:540-551

Zedler JB (1980) Algal mat productivity: comparisons in a salt marsh. Estuaries 3:122-131

Submitted: November 19, 2003; Accepted: August 3, 2004 Proofs received from author(s): October 25, 2004 